DEVELOPMENT REPORT

HANFORD ATOMIC PRODUCTS OPERATION

RICHLAND, WASHINGTON 


\section{DISCLAIMER}

This report was prepared as an account of work sponsored by an agency of the United States Government. Neither the United States Government nor any agency Thereof, nor any of their employees, makes any warranty, express or implied, or assumes any legal liability or responsibility for the accuracy, completeness, or usefulness of any information, apparatus, product, or process disclosed, or represents that its use would not infringe privately owned rights. Reference herein to any specific commercial product, process, or service by trade name, trademark, manufacturer, or otherwise does not necessarily constitute or imply its endorsement, recommendation, or favoring by the United States Government or any agency thereof. The views and opinions of authors expressed herein do not necessarily state or reflect those of the United States Government or any agency thereof. 


\section{DISCLAIMER}

Portions of this document may be illegible in electronic image products. Images are produced from the best available original document. 


\section{LEGAL NOTICE}

This report was prepared as an account of Government sponsored work. Neither the United States, nor the Commission, nor any person acting on behalf of the Commission:

A. Makes any warranty or representation, expressed or implied, with respect to the accuracy, com. pleteness, or usefulness of the information contained in this report, or that the use of any information, apparatus, method, or process disclosed in this report may not infringe privately owned rights; or

B. Assumes any liabilities with respect to the use of, or for damages, resulting from the use of any information, apparatus, method, or process disclosed in this report.

As used in the above, "person acting on behalf of the Commission" includes any employee or contractor of the Commission, or employee of such contractor, to the extent that such employee or con. tractor of the Commission, or employee of such contractor prepares, disseminates, or provides access 10, any information pursuant to his employment or contract with the Commission, or his employment with such contractor. 


$$
\begin{gathered}
\text { HW }-76973 \text { REV } \\
\text { UC-70, Waste Disposal } \\
\text { and Processing } \\
\text { (TID-4500, 27th Ed.) }
\end{gathered}
$$

\title{
DENITRATION OF PUREX WASTES WITH SUGAR
}

By

\author{
L. A. Bray \\ Chemical Laboratory \\ Chemical Research Operation \\ Hanford Laboratories
}

April 1963

FIRST UNRESTRICTED
DISTRIBUTION MADE

\section{HANFORD ATOMIC PRODUCTS OPERATION \\ RICHLAND, WASHINGTON}

Work performed under Contract No. AT (45-1)-1350 between the Atomic Energy Commission and General Electric Company

Printed by/for the U. S. Atomic Energy Commission

Printed in USA. Price $\$ 0.50$ Available from the Office of Technical Services

Department of Commerce

Washington $25, \mathrm{D}$. C.

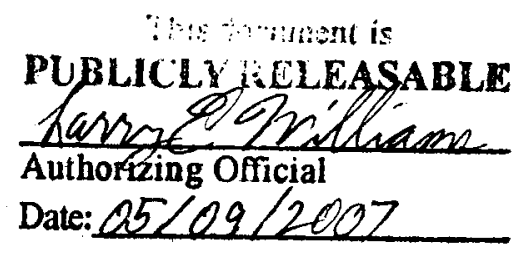




\section{TABLE OF CONTENTS}

INTRODUCTION

SUMMARY 1

EXPERIMENTAL 3

RESULTS AND DISCUSSION 4

Denitration Mechanism 4

Denitration as a Function of Acid Concentration 5

Denitration as a Function of the Metallic Salt Concentration 6

$\begin{array}{ll}\text { Denitration as a Function of Time } & 9\end{array}$

Process Denitration 13

Other Potential Sources of Sugar 13

Hot-Cell, Semiworks, and Purex Plant Demonstrations 16

ACKNOWLEDGMENTS 18

REFERENCES $\quad 19$ 


\section{DENITRATION OF PUREX WASTES WITH SUGAR}

\section{INTRODUCTION}

Sugar is being used as a denitrating agent for the Purex Solvent Extraction Plant at Hanford. Denitration of the waste stream of a nuclear fuels reprocessing facility, such as Purex, has been investigated for several years. $(1-7)$ The goal is to destroy the original $\mathrm{HNO}_{3}$ concentration of a pproximately 5 to $10 \underline{M}$ to a minimum residual product acidity of about $0.5 \underline{M}$ free acid. The advantages of an acid destruction would include (1) reduction of the concentration of $\mathrm{NaOH}$ ultimately required to neutralize the wastes for long term alkaline storage, (2) a volume reduction of the final stored wastes, (3) an easier and more economical recovery of fission products or other valuable residual trace components due to the decreased acidity and smaller processing volumes, and (4) a reduction of the sodium content in the waste, since sodium adversely affects the efficiency of many of the anticipated fission product recovery processes.

A denitration unit was placed in operation at the Purex plant during 1962 using formaldehyde to treat radioactive acidic wastes. Because of difficulties encountered during initial plant use of formaldehyde, a study of alternate methods of denitration was undertaken. Observations during the ion-exchange strontium recovery program indicated that rapid destruction of $\mathrm{HNO}_{3}$ occurs in the presence of certain organic complexants plus radiation. This phenomena was accordingly explored further in the laboratory (using a $\mathrm{Co}^{60}$ source and synthetic, nonradioactive solutions) for potential application to the denitration of Purex waste (where the fission products would provide the source of radiation). Several reagents, notably critic, ethylenediaminetetraacetic, and tartaric acids were effective in the presence of radiation. Sucrose reacted with $\mathrm{HNO}_{3}$ in synthetic Purex waste ( $1 \mathrm{WW}$ ) at an appreciable rate even in the absence of radiation.

\section{SUMMARX}

A process has been developed in the laboratory for the destruction of $\mathrm{HNO}_{3}$ in Purex-type waste solutions. The denitration process has also 
been successfully tested in the high level "hot" cells, the "cold" pilot plant denitration unit, and in the Purex plant. Polyhydroxy compounds such as sucrose, fructose, glucose, and crude syrups such as "black strap" molasses rapidly and controllably decompose $\mathrm{HNO}_{3}$ in aqueous solutions at temperatures above approximately $85 \mathrm{C}$. The number of moles of $\mathrm{HNO}_{3}$ destroyed per mole of sugar fed is a function of the temperature of reaction and the moles of dissolved multivalent metal cations (iron, chromium, etc.). The efficiency of destruction of $\mathrm{HNO}_{3}$ does not vary with acid concentration over the range of 0.5 to $8 \underline{\mathrm{M}}$. Destruction of acid does vary with iron concentration. Approximately 12 to 20 moles of $\mathrm{HNO}_{3}$ are destroyed per mole of sucrose fed as the iron concentration increases from 0 to 1 M.

The sugar reaction, although sufficiently rapid for convenient plant time cycles and for continuous or semicontinuous operation, is much less vigorous and exothermic than the formaldehyde reaction and can be safely carried out in large batch equipment, such as the existing Purex plant processing tanks of several thousand gal capacity. The reaction rate is easily controlled by the rate of sugar addition.

The products of the denitration reaction are all gaseous, consisting of oxides of carbon and nitrogen. No residual carbon or organic compounds remain in the treated solutions to complicate further processing or storage. $\mathrm{HNO}_{3}$ can be regenerated from the off-gasses by use of conventional down-draft condensers.

Economics of denitration of Purex wastes are highly dependent on the cost of sugar. At present prices of $10 \phi / 1 \mathrm{~b}$ for refined sucrose and $4 \not / 1 b$ for $37 \%$ formaldehyde, reagent costs alone for sucrose denitration are slightly higher than for formaldehyde, based on 18 moles and 2.2 moles of $\mathrm{HNO}_{3}$ destroyed per mole of the respective reagents. This is equivalent to $3.04 \not / 1 \mathrm{~b}$ of acid destroyed using sucrose and $2.37 \phi / 1 \mathrm{~b}$ of acid destroyed using formaldehyde. The reagent costs using molasses would be $1.17 \not 1 / 1 b$ of acid destroyed. Total costs for sugar denitration in a new plant might be substantially lower than formaldehyde even with refined sucrose because of the simpler equipment and instrumentation required. 
Sugar denitration is not limited to Purex-type wastes but should be applicable to treatment of other $\mathrm{HNO}_{3}$ solutions, either radioactive or non radioactive.

\section{EXPERIMENTAL}

For laboratory and hot-cell demonstrations, a sugar solution was added either incrementally or batch-wise to synthetic or actual acidic wastes (Table I) and heated. Samples were taken at various time intervals and analyzed for residual carbon, hydrogen ion, and nitrate concentrations. The total nitrate concentration was determined by a phenoldisulfonic acid colorimetric method. The hydrogen ion concentration was determined by complexing the iron in a sample with ammonium oxalate and titrating the resulting solution to the original $\mathrm{pH}$ with $\mathrm{NaOH}$. The residual carbon concentration was determined by placing a liquid sample in a platinum boat, drying and heating the resulting product in an oxygen atmosphere to $1000 \mathrm{C}$, and passing the resulting gas through a standard gas train. The resulting $\mathrm{CO}_{2}$ was determined by the change in weight of a sodium hydrate asbestos absorbent.

\section{TABLE I}

COMPOSITION OF A TYPICAL PUREX ACIDIC WASTE

\begin{tabular}{c} 
Constituent \\
\hline $\mathrm{H}^{+}$ \\
$\mathrm{Fe}(\mathrm{III})$ \\
$\mathrm{Ai}(\mathrm{III})$ \\
$\mathrm{Ni}(\mathrm{II})$ \\
$\mathrm{Cr}(\mathrm{III})$ \\
$\mathrm{Na}^{+}$ \\
$\mathrm{NO}_{3}^{-}$ \\
$\mathrm{SO}_{4}=$ \\
$\mathrm{PO}_{4}$ \\
Fission Products
\end{tabular}

Molarity

4 to 8

0.5 to 1.0

0.1

0.2

0.1

0.68

5 to 7

0.7

0.01

Trace 


\section{RESULTS AND DISCUSSION}

\section{Denitration Mechanism}

The products of denitration of acidic wastes with polyhydroxy compounds such as sucrose $\left(\mathrm{C}_{12} \mathrm{H}_{22} \mathrm{O}_{11}\right)$ are all gaseous, consisting of oxides of carbon and nitrogen. Sugar (sucrose), upon hydrolysis with acids, yields glucose and fructose in equal amounts. The hydrolysis and oxidation of the glucose portion of the sugar then follows a step-wise reaction sequence similar to that listed in the following set of equations, Figure 1.
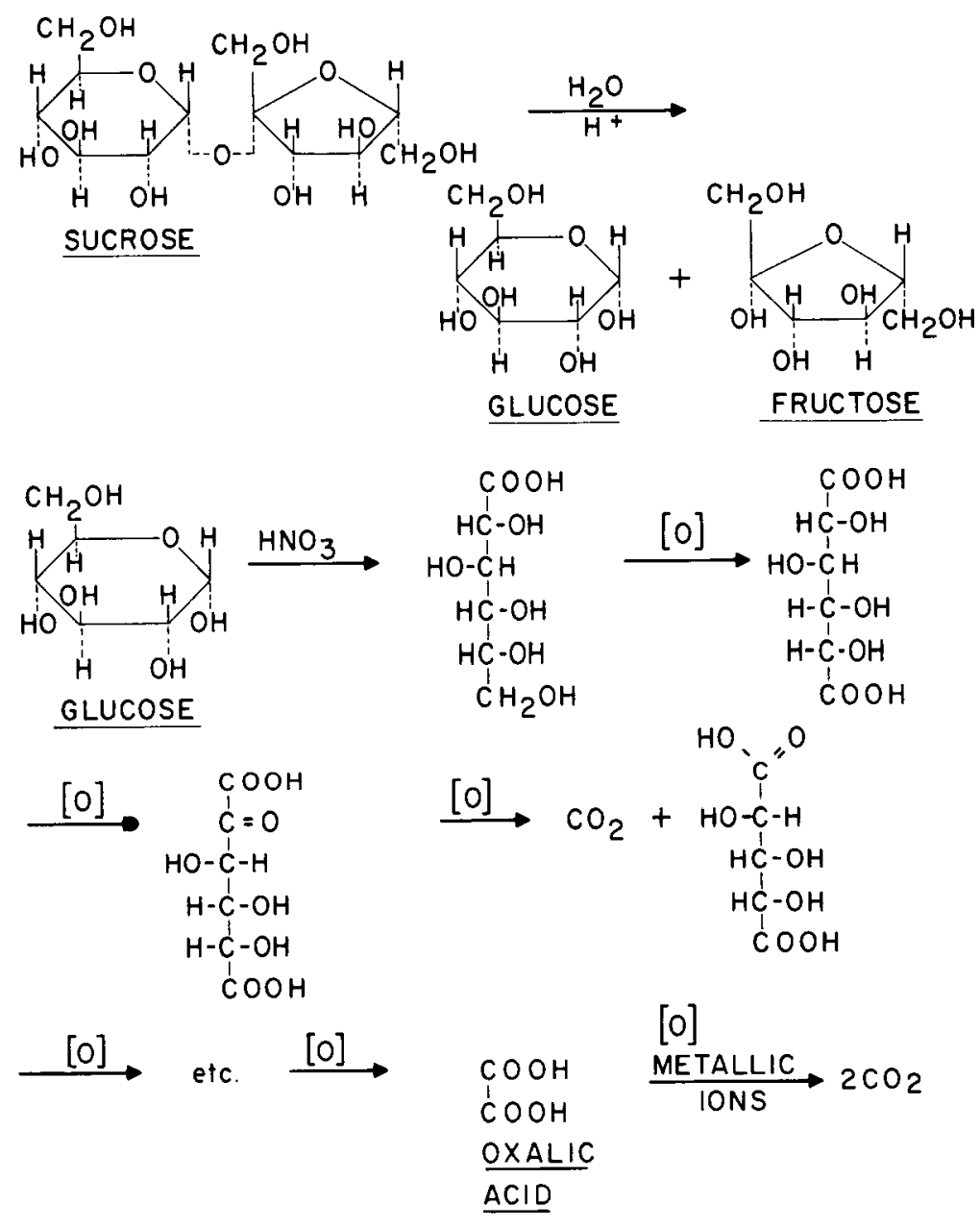

FIGURE 1

Oxidation of Sucrose 
The oxidation of the fructose moiety follows a reaction sequence similar to that of the glucose portion. From these equations, it can be seen that two hydrolysis reactions and at least three oxidation reactions are required before any evolution of gaseous $\mathrm{CO}_{2}$ will occur. It is not surprising therefore that a relatively long induction period of from 6 to $10 \mathrm{~min}$ has been noted for this oxidation reaction.

$$
\begin{aligned}
& 12 \mathrm{HNO}_{3}+\mathrm{C}_{12} \mathrm{H}_{22} \mathrm{O}_{11}-12 \mathrm{CO}+6 \mathrm{~N}_{2} \mathrm{O}_{3}+17 \mathrm{H}_{2} \mathrm{O} \\
& 12 \mathrm{HNO}_{3}+6 \mathrm{NO} \rightarrow 18 \mathrm{NO}_{2}+6 \mathrm{H}_{2} \mathrm{O} \\
& 24 \mathrm{HNO}_{3}+12 \mathrm{CO} \rightarrow 24 \mathrm{NO}_{2}+12 \mathrm{CO}_{2}+12 \mathrm{H}_{2} \mathrm{O} \\
& \mathrm{C}_{12} \mathrm{H}_{22} \mathrm{O}_{11}+48 \mathrm{HNO}_{3} \rightarrow 48 \mathrm{NO}_{2}+12 \mathrm{CO}_{2}+35 \mathrm{H}_{2} \mathrm{O}
\end{aligned}
$$

According to these reactions, the observed efficiency could range from 12 to 48 moles of $\mathrm{HNO}_{3}$ destroyed per mole of sucrose consumed.

\section{Denitration as a Function of Acid Concentration}

The use of sucrose for the destruction of $\mathrm{HNO}_{3}$ has been suggested as an alternate for the current formaldehyde procedure. It is therefore necessary to compare the two processes. The British Atomic Energy Establishment $(1-3)$ has investigated the formaldehyde reaction extensively and found that if formaldehyde is added to concentrated $\mathrm{HNO}_{3}$, initially 4 moles of $\mathrm{HNO}_{3}$ are destroyed per mole of formaldehyde; but as the acid concentration decreases, a different mechanism comes into play. As the $\mathrm{HNO}_{3}$ concentration decreases, the reaction finally approximates a $1: 1$ ratio. The destruction of $\mathrm{HNO}_{3}$ with sucrose is not similar but is linear with acid concentration, i.e., the sucrose reaction destroys the same number of moles of acid at all acid concentrations.

The destruction of $\mathrm{HNO}_{3}$ was determined as a function of acid concentration by adding increments of sucrose equivalent to approximately $0.03 \mathrm{M}$ of sucrose per liter of synthetic $1 \mathrm{WW}$, to a solution containing an original $8 \mathrm{M}$ 
$\mathrm{HNO}_{3}$. Each increment added to the acid solution was refluxed (95 to $105 \mathrm{C}$ ) for 4 to $6 \mathrm{hr}$. Samples were taken after each reflux and analyzed for the concentration of the remaining undestroyed $\mathrm{HNO}_{3}$ before each additional sucrose addition. Figure 2 shows that the destruction of $\mathrm{HNO}_{3}$ is linear with acid concentration, implying that the same mechanism exists over this range of acid concentrations.

Denitration as a Function of the Metallic Salt Concentration

T. V. Healy $(1,3)$ noted that the presence of ferric or uranyl nitrates found in fission product solutions catalyzed the reaction of both concentrated or dilute $\mathrm{HNO}_{3}$ with both formic acid and formaldehyde. The stoichiometry of the sucrose denitration reaction (moles of $\mathrm{HNO}_{3}$ destroyed per mole of sucrose fed) and the speed of the reaction with added metal salts were briefly studied.

Results for the sucrose denitration of several $\mathrm{HNO}_{3}$ solutions were obtained in which the ferric salt concentration was varied from 0 to 1 MI. Table II and Figure 3 show the results for hydrogen ion, nitrate, and residual carbon concentrations after the sucrose and acid reacted at $100 \mathrm{C}$ for approximately $24 \mathrm{hr}$.

The moles of $\mathrm{HNO}_{3}$ destroyed per mole of sucrose fed varied from 11.5 to 20.5 with 0 to $1 \mathrm{M}$ ferric salt. Figure 3 shows that the residual carbon remaining after $24 \mathrm{hr}$ is also a function of the iron concentration in the initial acid solution.

TABLE II

\begin{tabular}{|c|c|c|c|c|c|c|c|}
\hline \multirow[b]{3}{*}{$\begin{array}{l}\text { Reaction } \\
\text { Time, hr }\end{array}$} & \multicolumn{6}{|c|}{ DESTRUCTION OF NITRIC ACID } & \\
\hline & \multicolumn{7}{|c|}{$\begin{aligned} \text { Conditions: } & 400 \mathrm{ml} \text { of } 6 \mathrm{M} \mathrm{HNO}_{3}, \text { varying } \mathrm{Fe}\left(\mathrm{NO}_{3}\right)_{3} \\
& 40 \mathrm{ml} \text { of } 2 . \overline{5 \mathrm{M}} \text { Sucrose }(14.4 \text { grams of carbon) }\end{aligned}$} \\
\hline & $\begin{array}{l}\mathrm{Fe} \\
\underline{\mathrm{M}}\end{array}$ & $\begin{array}{l}\mathrm{H}^{+} \\
\underline{\mathrm{M}}\end{array}$ & $\begin{array}{r}\mathrm{TO}_{3} \\
\mathrm{M}^{-} \\
\end{array}$ & $\begin{array}{l}\text { mperature, } 10 \\
\text { Residual }(a) \\
\text { Carbon, }{ }^{(a)} \\
\end{array}$ & \multirow{3}{*}{$\begin{array}{c}\begin{array}{c}\text { Volume, } \\
\mathrm{ml}\end{array} \\
\begin{array}{c}400 \\
405\end{array}\end{array}$} & \multicolumn{2}{|c|}{$\begin{array}{l}\text { Moles } \mathrm{HNO}_{3} \text { Destroyed } \\
\text { per Mole Sucrose Fed } \\
\text { (b) }\end{array}$} \\
\hline- & - & 6.27 & 5.9 & - & & - & - \\
\hline 24 & & 3.36 & 2.8 & 2.09 & & 11.5 & 12.3 \\
\hline 28 & 0.1 & $\begin{array}{l}\text { 6. } 18 \\
2.25\end{array}$ & $\begin{array}{l}6.0 \\
2.4\end{array}$ & $4 . \overline{9}$ & $\begin{array}{l}400 \\
400\end{array}$ & $\begin{array}{r}- \\
15 \cdot 7\end{array}$ & 14.4 \\
\hline $\begin{array}{l}- \\
19 \\
23.5\end{array}$ & 0.5 & $\begin{array}{l}\text { 6. } 19 \\
1.60 \\
1.61\end{array}$ & $\begin{array}{l}\text { 7. } 2 \\
\text { 3. } 1 \\
\text { 3. } 0\end{array}$ & $\begin{array}{l}-\overline{4} \\
3.4 \\
0.69\end{array}$ & $\begin{array}{l}400 \\
374 \\
374\end{array}$ & $\begin{array}{l}- \\
18.8 \\
18.8\end{array}$ & $\begin{array}{l}- \\
17.2 \\
17.6\end{array}$ \\
\hline $\begin{array}{r}- \\
19 \\
24\end{array}$ & 1.0 & $\begin{array}{l}6.15 \\
1.09 \\
1.14\end{array}$ & $\begin{array}{l}8.8 \\
3.9 \\
3.9\end{array}$ & $\begin{array}{l}- \\
0.63 \\
0.21\end{array}$ & $\begin{array}{l}400 \\
379 \\
379\end{array}$ & $\begin{array}{l}- \\
20.5 \\
20.3\end{array}$ & $\begin{array}{l}- \\
20.4 \\
20.4\end{array}$ \\
\hline $\begin{array}{l}\text { (a) } \mathrm{Ba} \\
\text { (b) } \mathrm{Ba} \\
\text { (c) } \mathrm{Ba}\end{array}$ & $\begin{array}{l}d \text { on } \\
\text { d } \text { on } \\
d \text { d on }\end{array}$ & $\begin{array}{l}\text { ercent } \\
\text { ree aci } \\
\mathrm{O}_{2}-\mathrm{N}+\mathrm{N}\end{array}$ & $\begin{array}{l}\text { of tot: } \\
\text { d anal } \\
\mathrm{O}_{3}^{-} \mathrm{a}\end{array}$ & $\begin{array}{l}\text { carbon fed as } \\
\text { ses } \\
\text { alyses }\end{array}$ & crose & & \\
\hline
\end{tabular}




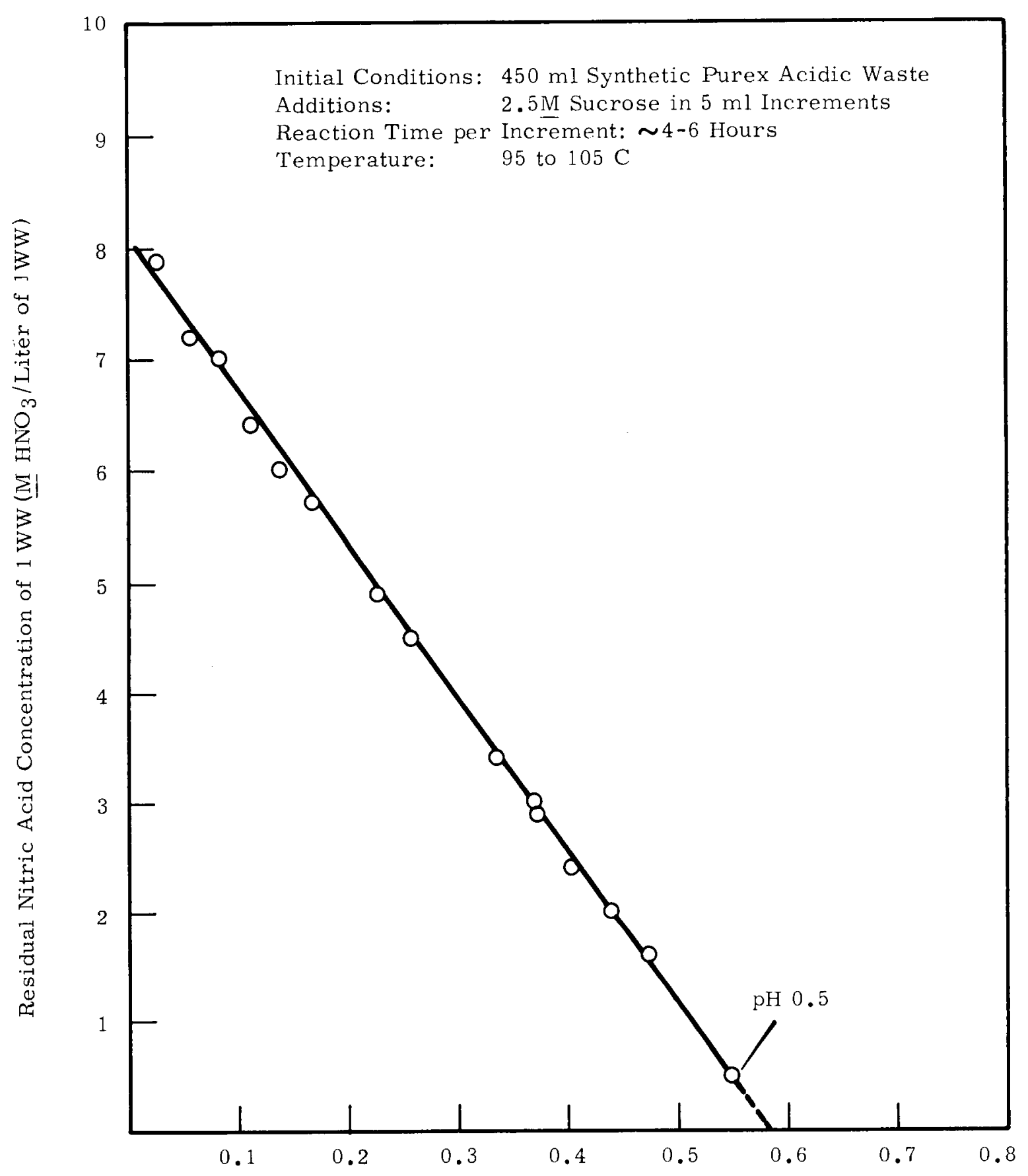

Cumulative Moles of Sucrose per Liter of $1 \mathrm{WW}$

FIGURE 2

Destruction of $\mathrm{HNO}_{3}$

(1WW with Sucrose as a Function of Acid Concentration) 


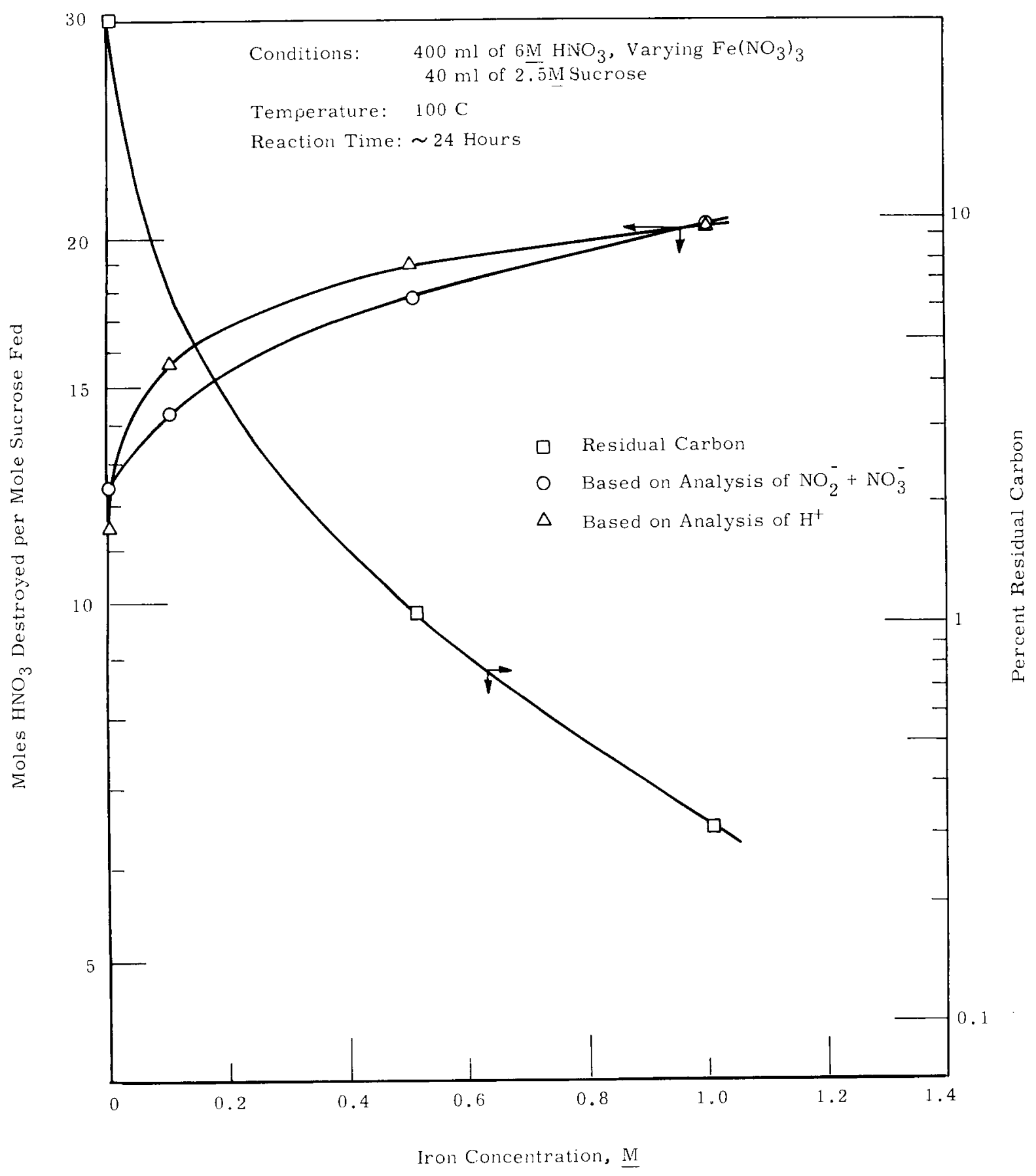

FIGURE 3

Denitration as a Function of Iron Concentration at a Constant Reaction Time 
The destruction of $\mathrm{HNO}_{3}$ with sugar will proceed with or without a catalyst such as iron, chromium, or other catalytic ions associated with fission product wastes. However, the catalytic effect, i,e., the change in reaction rate in the presence of or lack of such ions, should be taken into consideration as future waste concentrations change and for applications involving the denitration of purified fission product solutions.

Denitration as a Function of Time

The sucrose-HNO 3 reaction was studied to determine some of its properties. The reaction is easily controlled by rate of sucrose addition. The rate of gas evolution is a function of the catalyst, the reaction temperature, and the sucrose addition rate. The initial reaction temperature for rapid acid destruction is approximately $85 \mathrm{C}$, although it has been noted that once the reaction has started and then stopped, the restart temperature is much lower (approximately $50 \mathrm{C}$ ) and is probably due to the formation and catalytic effect of oxides of nitrogen such as nitrite.

The moles of $\mathrm{HNO}_{3}$ destroyed per mole of sucrose fed improved approximately $10 \%$ by increasing the reaction temperature from 85 to $100 \mathrm{C}$. The acid destruction was not improved with the use of a reaction tower above the reaction vessel, such as that required in the formaldehyde procedure. The initial induction period is only 6 to $9 \mathrm{~min}$ after the initial addition of sugar (before visible evidence of oxides of nitrogen), and air sparging reduced this period by a factor of 2 to 4 .

A number of laboratory batch denitration studies were performed to determine the acid destruction as a function of time. The results provided the technical basis for further testing of batch, semicontinuous and continuous denitrations in both the cold Semiworks and Purex plants. Typical results for the denitration of synthetic acidic waste $(0.8 \underline{\mathrm{M}} \mathrm{Fe})$ with time are shown in Table III and Figure 4. The reaction temperature was held constant at $100 \mathrm{C}$. Samples were periodically analyzed for residual carbon, hydrogen ion, and nitrate. Residual nitrate and hydrogen ion concentrations are shown in Figure 4 in terms of acid destruction, i.e., moles 


\section{TABLE III}

\section{DENITRATION OF ACIDIC W ASTE AS A FUNCTION OF TIME}

Conditions: $400 \mathrm{ml}$ Synthetic Purex Waste (0.8M Fe) $40 \mathrm{ml}$ of $2.5 \underline{\mathrm{M}}$ Sucrose

Temperature, $100 \mathrm{C}$

\begin{tabular}{|c|c|c|c|c|c|c|}
\hline \multirow{2}{*}{$\begin{array}{l}\text { Reaction } \\
\text { Time, min }\end{array}$} & \multirow{2}{*}{$\begin{array}{l}\mathrm{H}^{+} \\
\underline{\underline{\mathrm{M}}} \\
\end{array}$} & \multirow{2}{*}{$\begin{array}{c}\mathrm{NO}_{3} \\
\underline{\underline{\mathrm{M}}}\end{array}$} & \multirow{2}{*}{$\begin{array}{r}\text { Residual } \\
\text { Carbon, } \%_{0}(a) \\
\end{array}$} & \multirow{2}{*}{$\begin{array}{l}\text { Volume, } \\
\mathrm{ml} \\
\end{array}$} & \multicolumn{2}{|c|}{$\begin{array}{l}\text { Moles } \mathrm{HNO}_{3} \text { Destroyed } \\
\text { per Mole Sucrose Fed }\end{array}$} \\
\hline & & & & & (b) & (c) \\
\hline 0 & 6.49 & 8.0 & --- & 400 & $\ldots$ & $\ldots$ \\
\hline 10 & 3.74 & 4. 1 & 96.2 & 440 & 9.7 & 14.2 \\
\hline 30 & 3.44 & 3.8 & 50.5 & 430 & 11.4 & 16.0 \\
\hline 100 & 2.78 & 3.5 & 37.6 & 415 & 13.8 & 17.8 \\
\hline 300 & 1.84 & 3.5 & 9.61 & 395 & 19.1 & 18.5 \\
\hline 655 & 1.65 & 3.5 & 3.22 & 380 & 20.1 & 19.1 \\
\hline 1250 & 1.61 & 3.5 & 0.37 & 370 & 20.4 & 19.4 \\
\hline
\end{tabular}

(a) Based on percent of total carbon fed as sucrose

(b) Based on free acid analyses

(c) Based on $\mathrm{NO}_{2}^{-}+\mathrm{NO}_{3}^{-}$analyses

of nitrate or hydrogen ion destroyed per mole of sucrose fed. In the first 10 min of the batch reaction (after evolution of oxides of nitrogen) the results were 14 and 10 respectively. These results show that $49 \%$ of the original nitrate and $37 \%$ of the hydrogen ion were destroyed during the first 10 min, but only $4 \%$ of the total carbon content had been evolved as an oxide. The difference noted between the hydrogen ion and nitrate destroyed during the initial reaction is assigned to the intermediate formation of organic acids.

To define more fully the rate of sucrose (or residual carbon) destruction, several other batch denitration studies were performed; the results are shown in Figure 5. In these studies, the acidic waste was again mixed with sucrose, heated at $100 \mathrm{C}$, and periodically sampled to determine residual carbon as a function of time. The results show $60 \%$ of the sucrose destroyed after $60 \mathrm{~min}, 75 \%$ after $120 \mathrm{~min}$, and $99 \%$ after approximately $20 \mathrm{hr}$. In actual radioactive wastes, any remaining carbon should be destroyed by radiation. 


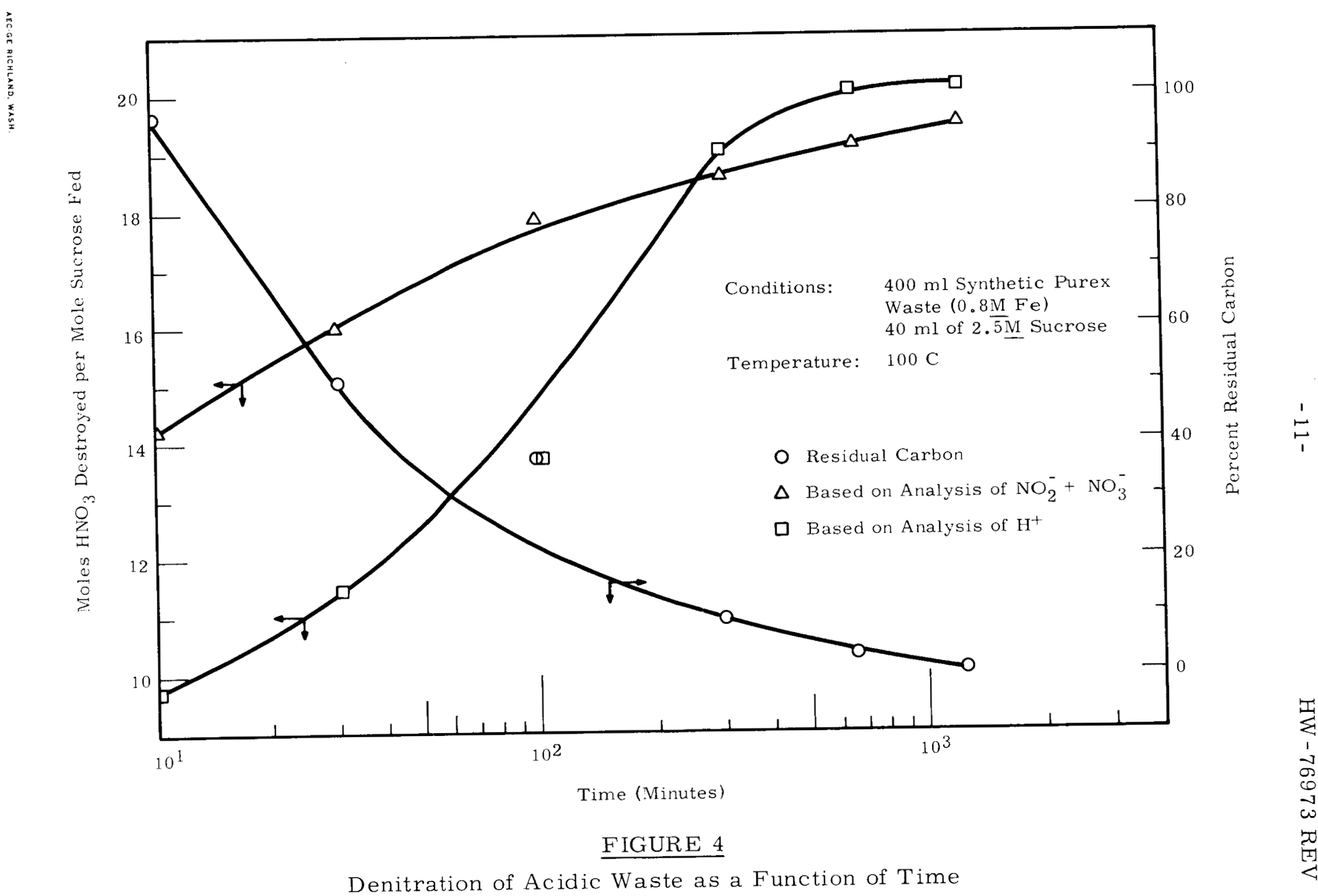




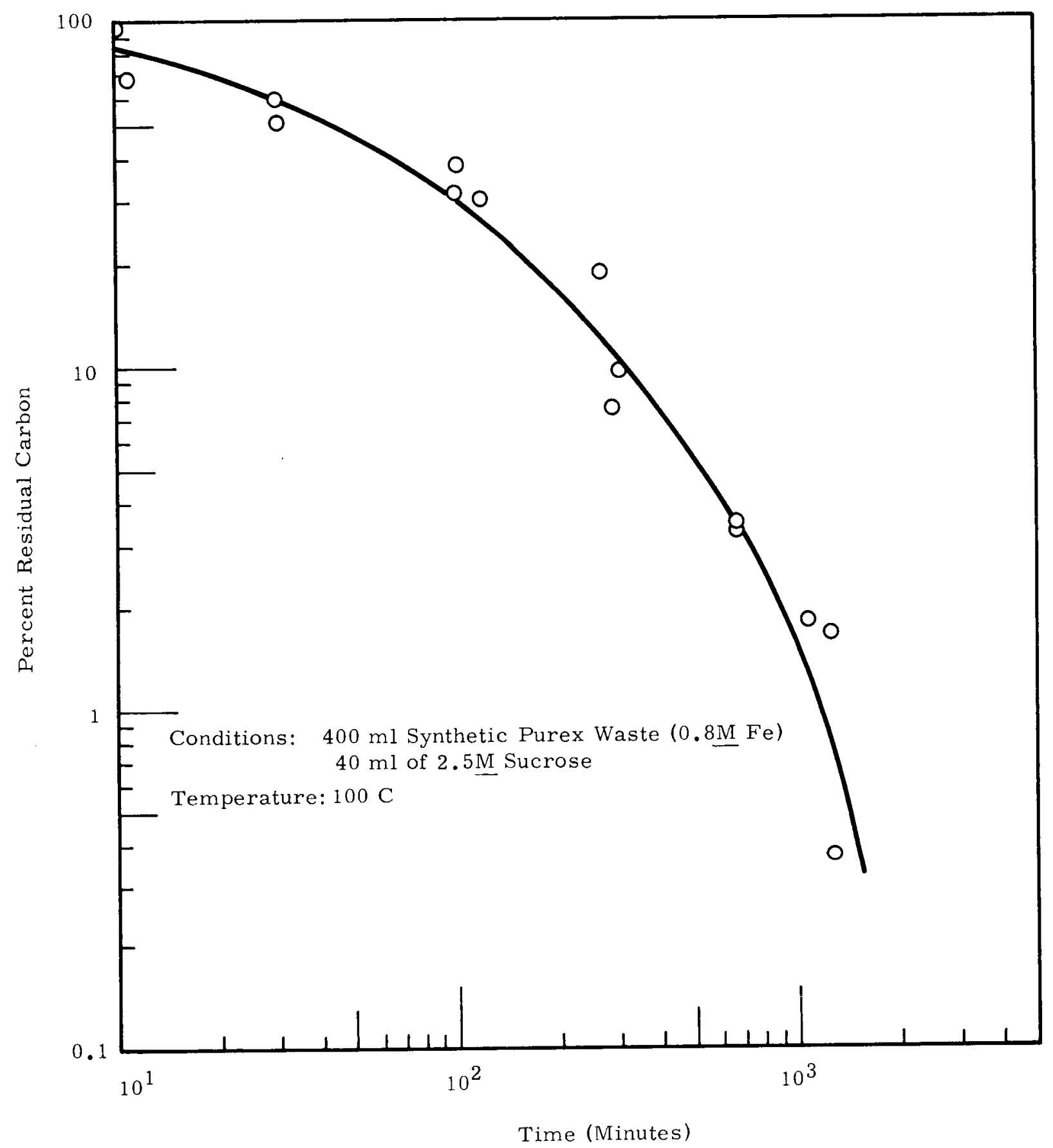

\section{FIGURE 5}

Residual Carbon as a Function of Time 
$\underline{\text { Process Denitration }}$

Denitration of solutions may be accomplished by (1) slowly adding sucrose to a full batch tank, (2) simultaneously filling the tank and adding sucrose during the same period, or (3) adding sucrose and fresh acidic waste continuously to a denitrated solution which is continuously being dumped as new material is added.

A laboratory test was run (simulating a proposed plant test) to evaluate the simultaneous addition of both sucrose and acidic waste into a heated reaction tank over a period of $50 \mathrm{hr}$. Major uncertainties were (1) whether the residual carbon content would be excessive, and (2) whether the acid destruction (moles of $\mathrm{HNO}_{3}$ destroyed per mole of sucrose fed) would be adequate. The test simulated the coaddition, to a 3000 gal tank, of 1 gal of acidic waste per minute and the required amount of sucrose to denitrate that gallon. Table IV shows that at the end of $50 \mathrm{hr}$ approximately 19 moles of $\mathrm{HNO}_{3}$ were destroyed per mole of sucrose fed and that the residual carbon content was a negligible 3\%. The success of this test indicates that the denitration of large quantities of waste may be accomplished as the waste is collected rather than after the reaction vessel is filled with waste.

Other Pcteritial Sources of Sugar

Batch denitration tests were performed to evaluate other potential sources of sugar. A "standard liquor" and a "thick juice" were obtained from the Utah-Idaho Sugar Company, Moses Lake, Washington. In addition, a supply of Hawaiian "black strap" molasses was obtained from the Pacific Molasses Co., Portland, Oregon.

Denitration comparative tests were obtained by mixing known volumes of sugar with a synthetic acid waste, heating to $100 \mathrm{C}$ and sampling at various time intervals. Analyses were obtained for hydrogen ion and residual carbon concentrations as shown in Table V. All sugar sources tested compared favorably with refined sucrose. Calcium and strontium impurities 
TABLE IV

SUCROSE DENITRATION TEST

To Simulate Addition of $1 \mathrm{gal} / \mathrm{min}$ to Purex 5000 gal Tank

Goal: $1500 \mathrm{ml} 1 \mathrm{WW}$ added in $3000 \mathrm{~min}$

Destruction of $\sim 20$ moles of $\mathrm{NO}_{3}^{-}$per mole of sucrose

Residual carbon $<2 \%$ at end of $3000 \mathrm{~min}$

Conditions: $0.5 \mathrm{mI} 1 \mathrm{WW} / \mathrm{min}, 0.089 \mathrm{~mL} 1.4 \mathrm{M}$ sucrose $/ \mathrm{min}$

Assume volume of pot equal to $\overline{W W}$ added

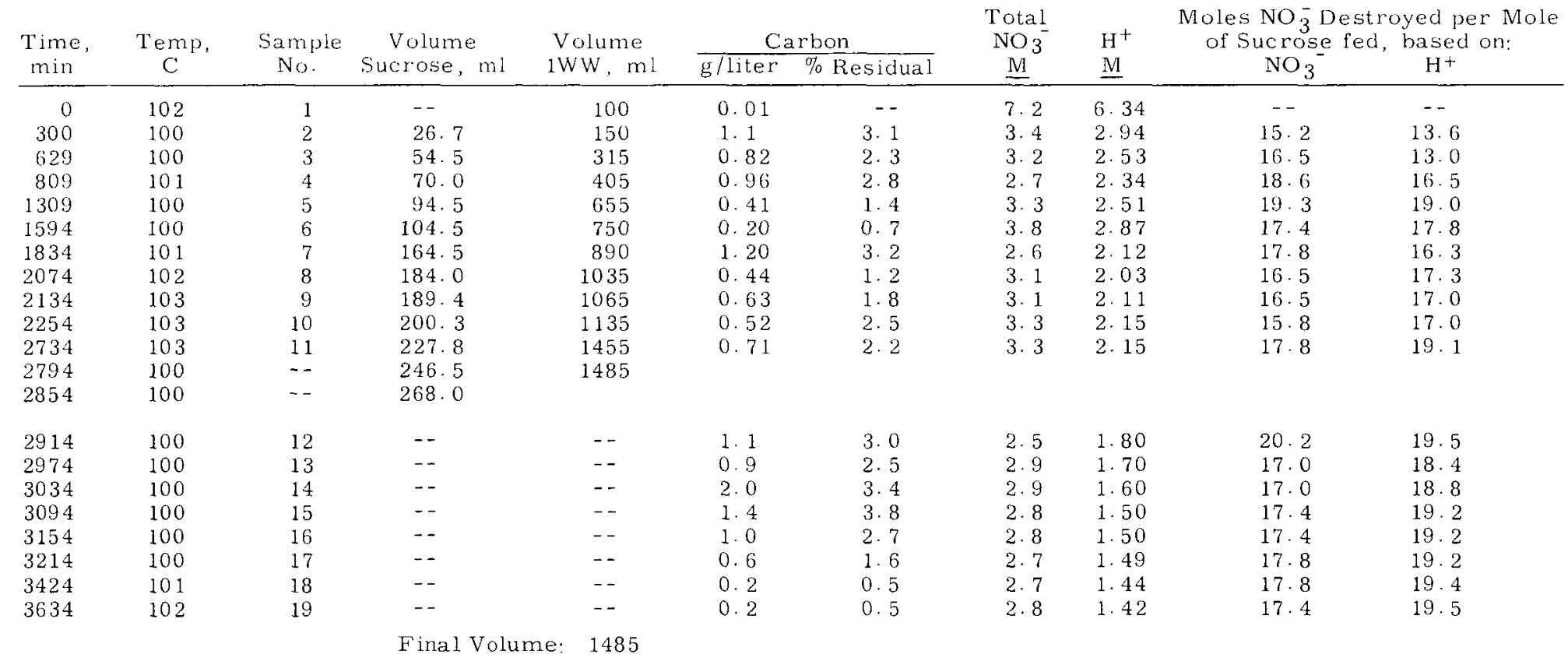


TABLE V

DENITRATION OF ACIDIC WASTE IN VARIOUS SUGARS

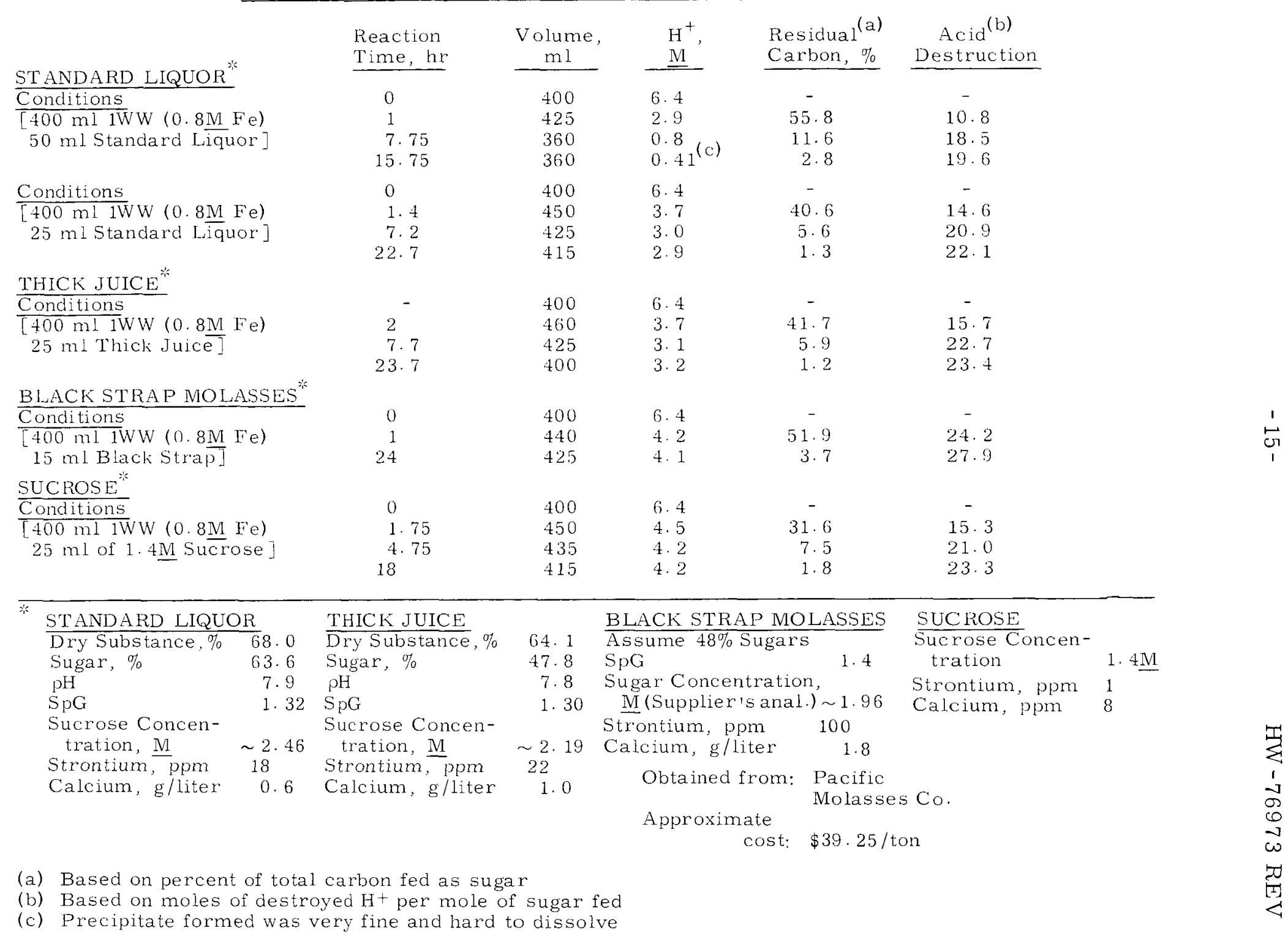


found in the various sources of sugar are reported because of their potential contamination to the fission product recovery program. The percent residual carbon and the moles of hydrogen ion destroyed per mole of molasses fed after $24 \mathrm{hr}$ of reaction both appear high as compared to the other sugars tested. This is probably due to the presence of other reactive carbonaceous materials in molasses, but not reported as sugar.

Hot Cell, Semiworks, and Purex Plant Demonstrations

In a hot-cell demonstration, using actual Purex radioactive acidic waste (1WW), $500 \mathrm{ml}$ of $1 \mathrm{WW}$ were heated in an open beaker with $40 \mathrm{ml}$ of 2M sucrose for $2.5 \mathrm{hr}$. To simulate a worst possible case, all of the sucrose was added initially, and the solution was quickly heated to $100 \mathrm{C}$. Evolution of oxides of nitrogen was initially vigorous, but controllable, and there was little or no tendency to foam (foam height less than $1 / 2 \mathrm{in.}$ ). The nitrate concentration was reduced from 5.3M to $1.06 \underline{\mathrm{M}}$ in $2.5 \mathrm{hr}$ for an $80 \%$ overall denitration or an efficiency of 21 moles of $\mathrm{HNO}_{3}$ per mole of sucrose fed.

To define a flowsheet for a Purex plant test, denitration studies have also been investigated in the cold Semiworks plant. Thirteen detailed runs have been completed by $E$. A. Coppinger ${ }^{(10)}$ using simulated feeds. Several proposed flowsheets have resulted from laboratory, hot-cell, and these semiworks studies. A possibie plant flowsheet was successfully demonstrated As shown in Figure 6, a 1. $\underline{4 M}$ sucrose solution was added to a batch of heated $(100 \mathrm{C}) 1 \mathrm{WW}$ over a period of $12 \mathrm{hr}$. The initial $\mathrm{HNO}_{3}$ concentration of the $1 \mathrm{WW}$ was 6.14M. After completion of the sucrose addition, samples were analyzed periodically to determine residual carbon, total nitrate, and hydrogen ion concentration as shown in Table VI,

The digestion time was extended in this test only to determine how the trace carbon was destroyed with time. About 19 moles of nitrate were destroyed per mole of sucrose fed. The hydrogen ion and total nitrate concentrations were nearly uniform after $24 \mathrm{hr}$ with a residual carbon content of less than $2 \%$. 


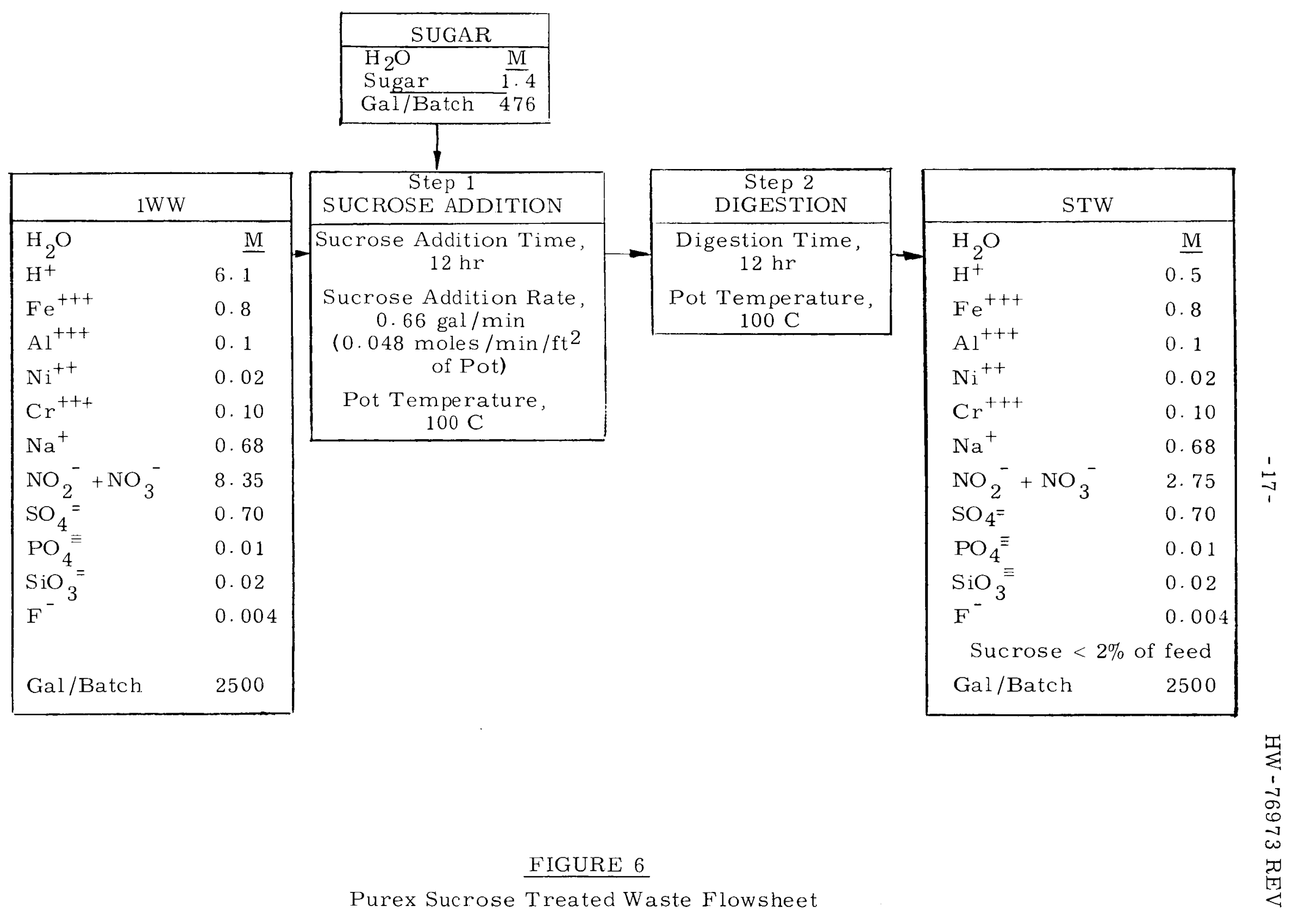


TABLE VI

SAMPLE ANALYSIS AFTER SUCROSE ADDITION

\begin{tabular}{|c|c|c|c|}
\hline $\begin{array}{l}\text { Time, } \\
\text { hr }\end{array}$ & $\begin{array}{c}\mathrm{H}^{+} \\
\mathrm{M}^{\prime} \\
\end{array}$ & $\begin{array}{c}\text { Nitrate, } \\
\mathrm{M} \\
\end{array}$ & $\begin{array}{l}\text { Residual } \\
\text { Carbon, \% }\end{array}$ \\
\hline 0 & 6.14 & 8.2 & - \\
\hline 12 & 2.0 & 3.4 & - \\
\hline 15 & 1.4 & 2.8 & - \\
\hline 18 & 1. 1 & 2.9 & 7.9 \\
\hline 21 & 1.0 & 2.8 & 4.1 \\
\hline 24 & 0.94 & 2.9 & 1.9 \\
\hline 27 & 0.96 & 2.9 & 1. 1 \\
\hline 30 & 0.90 & 2.9 & 0.4 \\
\hline
\end{tabular}

The sucrose process for the denitration of Purex waste was successfully tested $^{(11)}$ in the plant during February, 1963, culminating the laboratory and semiworks development. A 2500 gal batch of 1WW, initially $4.5 \mathrm{MI} \mathrm{H}^{+}$, was heated, and $1600 \mathrm{lb}$ of sucrose slowly added. The final hydrogen ion concentration was $0.68 \underline{\mathrm{M}}$ or 18.2 moles of $\mathrm{HNO}_{3}$ destroyed per mole of sucrose fed. Sugar has been adopted for routine plant use.

\section{ACKNOW LEDGMENTS}

The author is grateful to Mrs. Barbara Van der Cook and L. F. Lust for their work in development of analytical methods for residual carbon and nitrate, and to E. C. Martin, E. A. Coppinger, and Dr. Robert Lee Moore for the ir technical assistance. 


\section{REFERENCES}

1. T. V. Healy, and B. L. Ford. The Destruction of Nitric Acid by Formaldehyde, Part I, AERE-C - $\overline{R-1339}$, Atomic Energy Research Establishment, Harwell, England. April 2, 1954. (CONFIDENTIAL)

2. J. B. Morris. The Reaction of Nitric Acid with Formaldehyde, AERE-CE-R-1490, Atomic Energy Research Establishment, Harwell, England. October 12, 1954.

3. T. V. Healy, and B. L. Davies. The Destruction of Nitric Acid by Formaldehyde, Parts II, III and IV, AERE-C-R-1739, Atomic Energy Research Establishment, Harwe11, England. February 22, 1956.

4. G. B. Barton. The Removal of Nitric Acid from Purex Plant First Cycle Acid Waste (1WW) by Reaction with Formaldehyde, HW -55941. May 2, 1958.

5. T. F. Evans. The Pilot Plant Denitration of Purex Wastes with Formaldehyde, $\overline{H W-58587 . ~ F e b r u a r y ~ 23, ~} 1959$.

6. G. C. Oberg. Denitration of Purex Plant 1WW, HW-60161. May 1959. (SECRET)

7. R. C. Forsman, and G. C. Oberg. Formaldehyde Treatment of Purex Radioactive Wastes, HW-79622. October 1963.

8. L. A. Bray, and E. C. Martin. Use of Sugar to Neutralize Nitric Acid Waste Liquors, Invention Report, HW-75565. November 11, 1962.

9. E. C. Martin. Unpublished Data. (Private Communication, April, 1963)

10. E. A. Coppinger. Pilot Plant Denitration of Purex Waste with Sugar, HW - 77080. March 29, 1963.

11. W. S. Frank. Chemical Processing Department, Research and Engineering Operation, Monthly Report - February, 1963, HW-76848 G. March 8, 1963. (SECRET) 


\section{INTERNAL DISTRIBUTION}

Copy Number

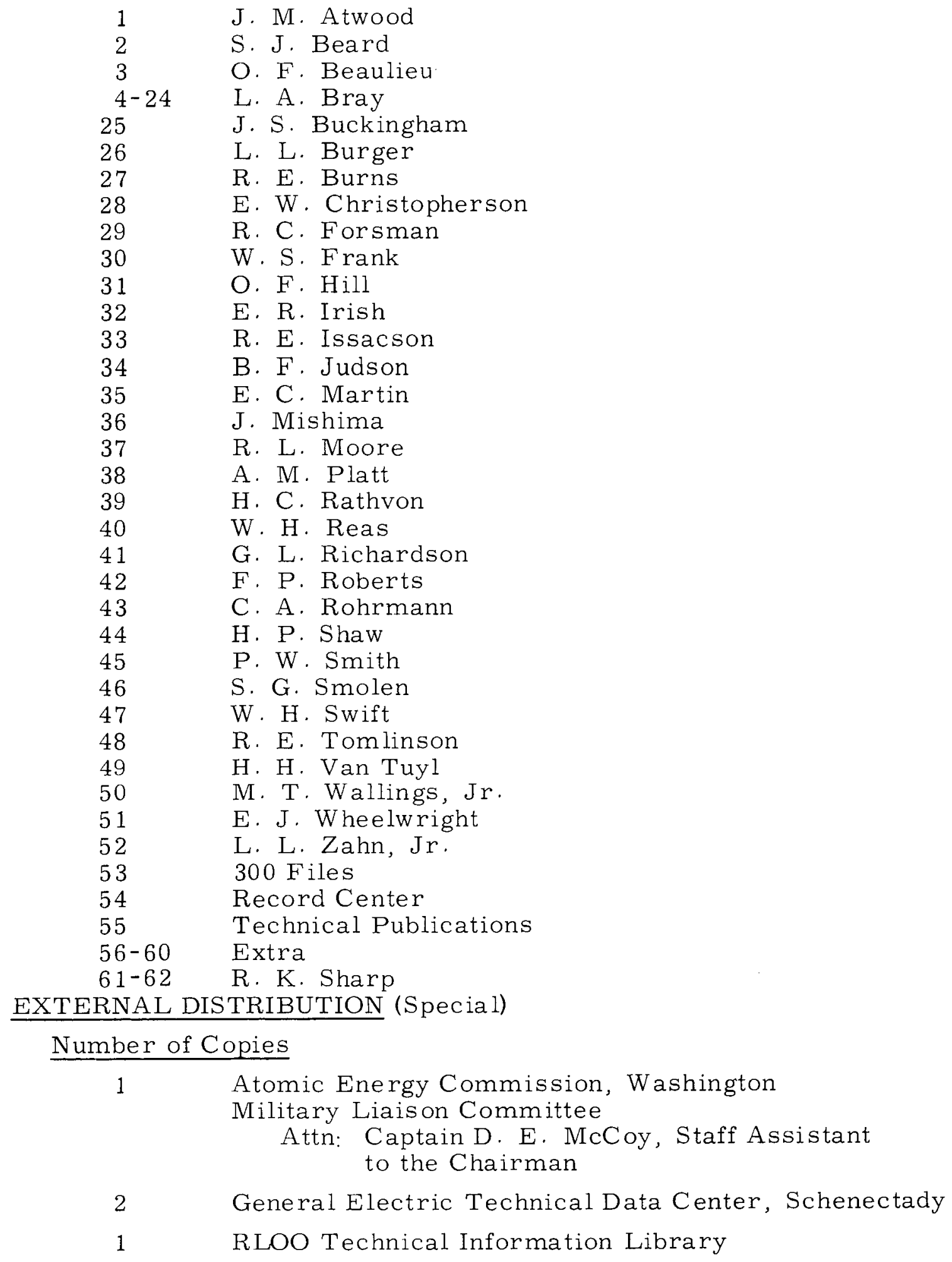


Pid.
Standard Distribution

BUREAU OF MEDICINE AND SURGERY

BUREAU OF MINES, ALBANY

BUREAU OF MINES, SALT LAKE CITY

BUREAU OF MINES, WASHINGTON

BUREAU OF SHIPS (CODE 1500)

BUREAU OF YARDS AND DOCKS

BURNS AND ROE, INC. (ERDL)

CALIFORNIA INSTITUTE OF TECHNOLOGY (ROSSANO)

CHANCE VOUGHT CORPORATION

CHICAGO PATENT GROUP

COMBUSTION ENGINEERING, INC.

COMMITTEE ON THE EFFECTS OF ATOMIC RADIATION

DEFENCE RESEARCH MEMBER

DIVISION OF RAW' MATERIALS, WASHINGTON

DOW CHEMICAL COMPANY, ROCKY FLATS

*DU PONT COMPANY, AIKEN

DU PONT COMPANY, WILMINGTON

EDGERTON, GERMESHAUSEN AND GRIER, INC., GOLETA

*EDGEWODD ARSENAL

FRANKFORD ARSENAL

FRANKLIN INSTITUTE OF PENNSYLVANIA

GENERAL ATOMIC DIVISION

GENERAL DYNAMICS/FORT WORTH

GENERAL ELECTRIC COMPANY, CINCINNATI

GENERAL ELECTRIC COMPANY, SAN JOSE

GENERAL INSTRUMENT CORPORATION

GIBBS AND COX, INC.

GOODYEAR ATOMIC CORPORATION

GRAND JUNCTION OFFICE

WAZLETOM NUCLEAR SOENCE CORPORATION

HUGHES AIRCRAFT COMPANY

IOWA STATE UNIVERSITY 
Ptd. Standard Distribution

1 JET PROPULSION LABORATORY

2
KELLY AIR FORCE BASE

KNCLLS ATCNIC POWEF LARGKATCRY

LOCKHEED.GEORGIA COMPANY

LOCKHE ED MISSILES AND SPACE COMPANY (NASA)

LOS ALANOS SCIENTIFIC LABORATORY

M \& C NUCLEAR, INC.

MALLINCKRODT CHEMICAL WORKS

MARITIME ADMINISTRATION

MARTIN-MARIETTA CORPORATION

MOUND LABORATORY

NASA LEWIS RESEARCH CENTER

NASA SCIENTIFIC AND TECHNICAL INFORMATION FACILITY

NATIONAL BUREAU OF STANDARDS

NATIONAL LEAD COMPANY OF OHIO

NAVAL CIVIL ENGINEERING LABORATORY

NAVAL POSTGRADUATE SCHOOL

NAVAL RADIOLOGICAL DEFENSE LABORATORY

NAVAL RESEARCH LABORATORY

NEVADA OPERATIONS OFFICE

NEW JERSEY STATE DEPARTMENT OF HEALTH

NEW YORK OPERATIONS OFFICE

NEW YORK UNIVERSITY (EISENBUD)

NUCLEAR MATERIALS AND EQUIPMENT CORPORATION

NUCLEAR METALS, INC.

OFFICE OF ASSISTANT GENERAL COUNSEL FOR PATENTS (AEC)

OFFICE OF INSPECTOR GENERAL

OFFICE OF NAVAL RESEARCH

OFFICE OF NAYAL RESEARCH (CODE 422)

DFFICE OF THE CHIFF OF FNGINEERS

OFFICE OF THE CHIEF OF NAVAL OPERATIONS

PHILLIPS PETROLEUM, COMPANY (NRTS)
MASSACHUSETTS INSTITUTE OF TECHNOLOGY
Ptd.
WASTE DISPOSAL AND PROCESSING

Standard Distribution

POWER REACTOR DEVELOPMENT COMPANY

PRATT AND WHITNEY AIRCRAFT DIVISION

PUBLIC HEALTH SERVICE

PUBLIC HEALTH SERVICE, CINCINNATI

PUBLIC HEALTH SERVICE, LAS VEGAS

PUBLIC HEALTH SERVICE, MONTGOMERY

PURDUE UNIVERSITY

RADIATION APPLICATIONS, INC.

RENSSELAER POLYTECHNIC INSTITUTE

REYHOLDS ELECTRICAL AND ENGINEERING COMPANY, INC.

SANDIA CORPORATION, ALBUQUERQUE

SCHENECTADY IAVAL REACTORS OFFICE

SECOND AIR FORCE (SAC)

SPACE TECHNOLOGY LABORATORIES, INC. (NASA)

STANFORD RESEARCH INSTITUTE

TENNESSEE VALLEY AUTHORITY

TODD SHIPYARDS CORPORATION

UNICH CARBIDE CORPORATICN (ORGDP)

UHTOH CATBRICE COKPCIATICN (CRNL)

UNION CAFBIDE COPPS SATISN (CRNL-Y-12)

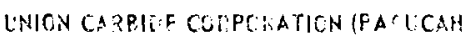
PLANT)

UNITED NUCLEAR COPPORATION (NDA)

U. 5. GEOLOGICAL SURYEY, ALBUQUERQUE

U. S, GEOLOGICAL SURVEY, DENYER

U. S. GEOLOGICAL SURVEY, NENLO PARK

U. S. GEOLOGICAL SURVEY (NOLAN)

U. S. GEOLOGICAL SURVEY, WASHINGTON

U. S. GEOLOGICAL SURYEY, WR DIVISION

J. S. WEATHER BUREAU, WASHINGTON

UNIVERSITY OF CALIFORNIA, BERKELEY

UNIVERSITY OF CALIFORNIA, DAVIS

UNIVERSITY OF CALIFURHIA, LIVERHORE

UNIVERSITY CF CALIFURNIA, LUS ANGFLES 
Ptd.
Standard Distribution

UNIVERSITY OF CALIFORNIA, SAN DIEGO

UNIVERSITY OF HAWAII

UNIVERSITY OF PUERTO RICO

UNIVERSITY OF ROCHESTER

WALTER REED ARMY MEDICAL CENTER

WESTINGHOUSE BETTIS ATCMIC POWER LABORATORY

WESTINGHOUSE ELECTRIC CORPORATION
Ptd.

1

325

$75+$
Standard Distribution

WESTINGHOUSE ELECTRIC CORPORATION (NASA)

DIVISION OF TECHNICAL INFORMATION EXTENSION

OFFICE OF TECHNICAL SERVICES,

WASHINGTON 